\title{
TINGKAT KREATIVITAS MAHASISWA MENGIDENTIFIKASI MERKURI (HG) PADA KRIM PEMUTIH WAJAH TIDAK TERDAFTAR BERBASIS PjBL (PROJECT BASED LEARNING)
}

\section{CREATIVITY LEVEL OF STUDENTS IDENTIFYING MERCURY (HG) IN FACE WHITENING CREAM NOT REGISTERED BASED ON PJBL (PROJECT BASED LEARNING)}

\author{
Heni Mulyani Pohan*, Elisa \& M. Rajab \\ Pendidikan Kimia, Fakultas Keguruan dan Ilmu Pendidikan Universitas Muhammadiyah Tapanuli Selatan \\ *Corresponding author: heni@um-tapsel.ac.id
}

\begin{abstract}
ABSTRAK
Kreativitas dalam proses pembelajaran merupakan salah satu soft skill yang perlu dikembangkan dalam memecahkan masalah pembelajaran maupun menghadapi dunia kerja di masa depan. Pembelajaran dengan pendekatan Project Based Learning menjadi salah satu pendekatan pembelajaran yang membangun kreativitas mahasiswa. Tujuan penelitian adalah adalah untuk mengetahui tingkat kreativitas mahasiswa dalam mengidentifikasi merkuri pada krim pemutih wajah tidak terdaftar berbasis Project Based Learning. Penelitian ini menggunakan metode eksperimen, dengan menggunakan kelas kontrol dan eksperimen. Hasil analisis data diperoleh tingkat kreativitas mahasiswa berdasarkan indikator (fluency of thinking, flexibility, elaboration dan originality) pada kelas kontrol dengan rata-rata 58\% dengan kategori cukup kreatif dan pada kelas eksperimen dengan rata-rata 78,75\% dengan kategori kreatif . Persentase kreativitas pada kelas kontrol sebesar 52\% dengan kategori kurang kreatif dan pada kelas eksperimen dengan persentase $73 \%$ dengan kategori kreatif. Hasil simpulan bahwa pembelajaran menggunakan pendekatan Project Based Learning dapat meningkatkan kreativitas mahasiswa.
\end{abstract}

Kata Kunci: Kreativitas; Project Based learning; Eksperimen.

\begin{abstract}
Creativity in the learning process is one of the soft skills that need to be developed in solving learning problems and facing the world of work in the future. Learning with the Project Based Learning approach is one of the learning approaches that builds student creativity. The purpose of the study was to find out what the level of student creativity is in identifying mercury in unregistered face whitening creams based on Project Based Learning. This study used an experimental method, using a control and experimental class. The results of data analysis obtained that the level of student creativity based on indicators (fluency of thinking, flexibility, elaboration and originality) in the control class with an average of $58 \%$ in the quite creative category and in the experimental class with an average of $78.75 \%$ in the creative category. The percentage of creativity in the control class is $52 \%$ in the less creative category and in the experimental class with a percentage of $73 \%$ in the creative category. The conclusion is that learning using a project based learning approach can increase student creativity.
\end{abstract}

Keywords: Creativity; Project based-learning; Experimental. 


\section{PENDAHULUAN}

Kreativitas dalam proses pembelajaran merupakan salah satu soft skill yang perlu dikembangkan dalam memecahkan masalah pembelajaran maupun menghadapi dunia kerja di masa depan. Kreativitas penting untuk dimunculkan, dipupuk dan dikembangkan ke dalam diri peserta didik karena: 1) mengenal cara mengekspresikan diri melalui hasil karya dengan menggunakan teknik-teknik yang dikuasainya, 2) mengenalkan cara dalam menemukan alternatif pemecahan masalah, 3) membuat anak memiliki sikap keterbukaan terhadap berbagai pengalaman, 4) membuat anak memiliki kepuasan diri terhadap apa yang dilakukannya dan sikap menghargai karya orang lain.

Pembelajaran sains merupakan salah satu cabang ilmu yang membutuhkan keterampilan kognitif tingkat tinggi, yang bertujuan membangun kerangka konseptual dan keterampilan proses sehingga membangun kreativitas berpikir tingkat tinggi dan berpikir kritis (Jatmiko, et al, 2018) Jadi, dapat dipahami bahwa kreativitas adalah karakteristik unik yang dimiliki oleh anak didik dalam proses pembelajaran. Karakteristik tersebut menjadi pondasi dasar dalam menemukan dan mengembangkan pemahaman serta pengembangan terhadap topik pembelajaran atau masalah pembelajaran. Dalam hal ini, kreativitas belajarmengajar tidak lepas dari konsep berpikir, emosi, nalar, dan intuisi. Dengan kata lain, indikator yang dapat digunakan dalam mengetahui tingkat kreativitas anak didik dalam proses pembelajaran mencakup fluency of thinking, flexibiligy, elaboration, and originality. Yeyen (2016).

Urgensi penelitian ini untuk melihat tingkat kreativitas mahasiswa dengan pendekatan project based learning untuk mengidentifikasi merkuri $(\mathrm{Hg})$ pada krim pemutih wajah tidak terdaftar. Kegiatan praktikum untuk mengidentifikasi kandungan merkuri pada krim pemutih wajah diharapkan mampu meningkatkan kreativitas yang tidak ditemukan pada mahasiswa kimia Universitas Muhammadiyah Tapanuli Selatan. Dalam hal ini, peneliti melihat bahwa mahasiswa tersebut belum menunjukkan kreativitas dalam mengikuti maupun mencapai hasil pembelajaran. Hal ini terlihat dari keterlibatan mahasiswa dalam kegiatan pembelajaran praktikum, di mana mahasiswa belum mampu menunjukkan tingkat kreativitas yang maksimal. Hal ini terlihat jelas dari kurangnya kesiapan serta rendahnya pemahaman mahasiswa dalam mengikuti pembelajaran praktikum. Akibatnya, tujuan dari pembelajaran praktikum tersebut tidak tercapai secara maksimal. Dengan demikian, kondisi tersebut menunjukkan bahwa tingkat kreativitas mahasiswa masih tergolong rendah atau kurang kreatif (Hasil Observasi Peneliti). Oleh sebab itu, peneliti beranggapan bahwa kondisi kreativitas mahasiswa tersebut perlu diberikan suatu upaya guna mencapai peningkatan kreativitas dalam melakukan praktikum pada materi logam transisi untuk mengidentifikasi merkuri dalam krim.

PjBL (Project Based Learning) merupakan penerapan dari pembelajaran aktif. Pembelajaran tersebut mencoba mengaitkan antara teknologi dengan masalah kehidupan sehari-hari yang akrab dengan anak didik, atau dengan proyek pembelajaran. Kemudian Titu (2015) menggambarkan langkah-langkah PjBL (Project Based Learning), yaitu: planning, creating, dan processing. Planning merupakan langkah pembelajaran yang bertujuan mempersiapakn segala kebutuhan proyek dalam proses pembelajaran. Creating adalah langkah menentukan asumsi, prediksi, maupun langkah-langkah investigasi dalam memecahkan proyek pembelajaran. Kemudian processing ialah langkah akhir dari proyek yang meliputi kegiatan presentasi hasil maupun evaluasi terhadap proyek pembelajaran.

Berkenaan tentang tingkat kreativitas pernah dilakukan penelitian sebelumnya oleh Rino Rhicardo (2014) disimpulkan bahwa siswa dengan gaya belajar visual memiliki kreativitas tingkat 3 (kreatif), hal ini karena siswa mampu menunjukkan indikator kefasihan-fleksibilitas dan kefasihankebaruan. Siswa dengan gaya belajar auditorial memiliki kreativitas tingkat 2 (kreatif), hal ini karena siswa mampu menunjukkan indikator kefasihan dan kebaruan. Selanjutnya Siswa dengan gaya belajar kinestetik memiliki kreativitas tingkat 1 (kurang kreatif). Sedangkan untuk analisis kadar merkuri. 


\section{METODE PENELITIAN}

Jenis Penelitian ini menggunakan metode eksperimen, yaitu penelitian yang dilakukan manipulasi bertujuan untuk mengetahui akibat manipulasi terhadap perilaku individu yang diamati. Manipulasi yang dilakukan dapat berupa situasi atau tindakan tertentu yang diberikan kepada individu atau kelompok, dan setelah itu dilihat pengaruhnya. Campbell \& Stanley (dalam Syaiful Indra, A., 2015) di mana menggunakan dua kelas yaitu kelas kontrol dengan pembelajaran konvensional dan kelas eksperimen dengan pembelajaran berbasis project based learning. Sampel penelitian diambil dengan teknik random sampling. Waktu Penelitian Penelitian ini dilaksanakan pada bulan Juni sampai Oktober 2020. Tempat Penelitian di Program Studi Pendidikan Kimia Fakultas Keguruan dan Ilmu Pendidikan (FKIP) Universitas Muhammadiyah Tapanuli Selatan. Sampel penelitian adalah mahasiswa yang telah menempuh mata kuliah praktikum kimia analitik.

Desain penelitian adalah desain kelompok pretest postest. Dalam penelitian ini diberi pretest dan postest pada kelompok kelas eksperimen dan kelompok kelas kontrol dengan soal yang sama sebelum dan sesudah diberi tindakan. Instrumen tes berupa soal keterampilan berpikir kreatif. Sementara instrumen nontes terdiri dari angket dan observasi. Teknik pengolahan data yang digunakan dalam penelitian ini yaitu validitas instrumen, reliabilitas instrumen, tingkat kesukaran, dan daya pembeda. Validitas instrumen digunakan untuk mengetahui kualitasdari instrumen tersebut. Reliabilitas digunakan untuk mengetahui seberapa konsisten skor tersebut untuk setiap individu. Tingkat kesukaran digunakan untuk mengetahui tingkat kesulitan yang dimiliki setiap soal. Daya pembeda digunakan keterampilan suatu soal dapat membedakan siswa yang berada di kelompok rendah dan kelompok atas. Ina Magdalena (2021).

Setelah didapatkan data kuntitatifdan data kualitatif dalam penelitian. Selanjutnya dilakukan tahap analisis data. Analisis data kuantitatif dilakukan dengan cara uji normalitas data, uji homogenitas, uji beda rata-rata dan uji gain ternormalisasi. Pengujian ini dilakukan dengan bantuan program SPSS 16.0 for windows. Ketentuan taraf signifikasi yang digunakan dalam penelitia ini yaitu 5\% $(\alpha=0,05)$ berdasarkan Pvalue. Analisis data kualitatif terdiri dari angket, lembarobservasi, catatan lapangan, dan wawancara. Angket yang digunakan dalam penelitian kualitatif ini yaitu angket yang berbentuk skala likert. Angket diberikan terbagi menjadi dua penyataan yaitu pernyataan positif dan pernyataan negatif. Lembar observasi dibuat dalam bentuk tabel dengan indikator dalam lembar observasi yang dikuantitatifkan

\section{HASIL DAN PEMBAHASAN}

Setelah dilakukan penelitian sebanyak tiga pertemuan di masing-masing kelas maka diperoleh data pre test dan postest siswa Selanjutnya data ini dianalisis untuk dapat menjawab rumusan masalah yang telah dibuat. Untuk menjawab tujuh rumusan tadi maka dilakukan uji hipotesis.

Pada pengujian hipotesis ini data yang dipakai yaitu data pretest dan postest keterampilan berpikir kreatif di kelas eksperimen. Selanjutnya dilakukan uji normalitas data. Data yang didapat ternyata berdistribusi tidak normal, makadilakukanujibedarata- rata dengan uji non-parametrik Mann-Whitney (uji-U). Hasil uji beda rata-rata menunjukkan bahwa terdapat perbedaan rata-rata nilai pretest dan postest siswa. Selanjutnya dilakukan uji hipotesis dengan menggunakan uji non paramatrik Wilcoxon. Hasil nya dapat dilihat di Tabel 1 berikut.

Tabel 1. Hasil Uji Hipotesis

\begin{tabular}{lr}
\hline & \multicolumn{1}{c}{ Pretest-Postest- eksperimen } \\
\hline$Z$ & -5.020 \\
\hline $\begin{array}{l}\text { Asymp. Sig. (2- } \\
\text { tailed) }\end{array}$ & $.00 \mathrm{C}$ \\
\hline
\end{tabular}


Berdasarkan hasil uji Wilcoxon diperoleh sig l-tailed sebesar 0,000. Data tersebut menunjukkan bahwa nilai sig 1 -tailed $\leq 0,05$ yang artinya menunjukkan bahwa $H_{0}$ ditolak, artinya pembelajaran menggunakan model project based learning dapat meningkatkan keterampilan berpikir kreatif siswa di kelas ekperimen. Pada pengujian hipotesis kedua adalah data yang dipakai yaitu data pretest dan postest keterampilan berpikir kreatif di kelas kontrol. Selanjutnya dilakukan uji normalitas data. Data yang didapat ternyata berdistribusi tidak normal, maka dilakukanujibedarata-ratadenganujinon- parametrik Mann-Whitney (ujiU). Hasil uji beda rata-rata menunjukkan bahwa terdapat perbedaan rata-rata nilai pretest dan postest siswa. Selanjutnya dilakukan uji hipotesis rumusan masalah kedua dengan menggunakan uji non paramatrik Wilcoxon. Untuk lebih jelasnya dapat dilihat Tabel 2 dibawah ini.

Tabel 2. Hasil Uji Hipotesis

\begin{tabular}{lr}
\hline & Pretest-postest \\
\hline $\mathrm{Z}$ & $-4.945^{\circ}$ \\
\hline $\begin{array}{l}\text { Asymp. Sig. (2- } \\
\text { tailed) }\end{array}$ & $.00 \mathrm{C}$ \\
\hline
\end{tabular}

Berdasarkan Tabel 2 didapat bahwa nilai sig (2-tailed) yaitu sebesar 0,000. Data tersebut menunjukkan bahwa nilai sig lebih kecildari pada $\alpha=0,05$ yang artinya bahwa $H_{0}$ ditolak dan $H_{1}$ diterima. Hal tersebut menunjukkan bahwa terdapat peningkatan terhadap keterampilan berpikir kreatif mahasiswa. Namun, untuk melihat apakah terdapat perbedaan peningkatan keterampilan berpikir kreatif mahasiswa yang mengikuti pembelajaran menggunakan model project based learning dan mahasiswa yang mengikuti pembelajaran menggunakan model konvensional maka dilakukan terlebih dahulu analisis dan interpretasi dari data yang diperoleh. Data yang dimaksud adalah data hasil pretest dan postest keterampilan berpikir kreatif dari kelas eksperimen dan kelas kontrol. Karena hasil postest pada kedua kelompok berdistribusi tidak normal maka akan dilihat dari peningkatan gain. Kemudian dilakukan pengujian dari data gain yang didapat darikeduakelas.Datagainkemudian di uji beda rata-rata menggunakan uji-t.

Tabel 3. Data uji t

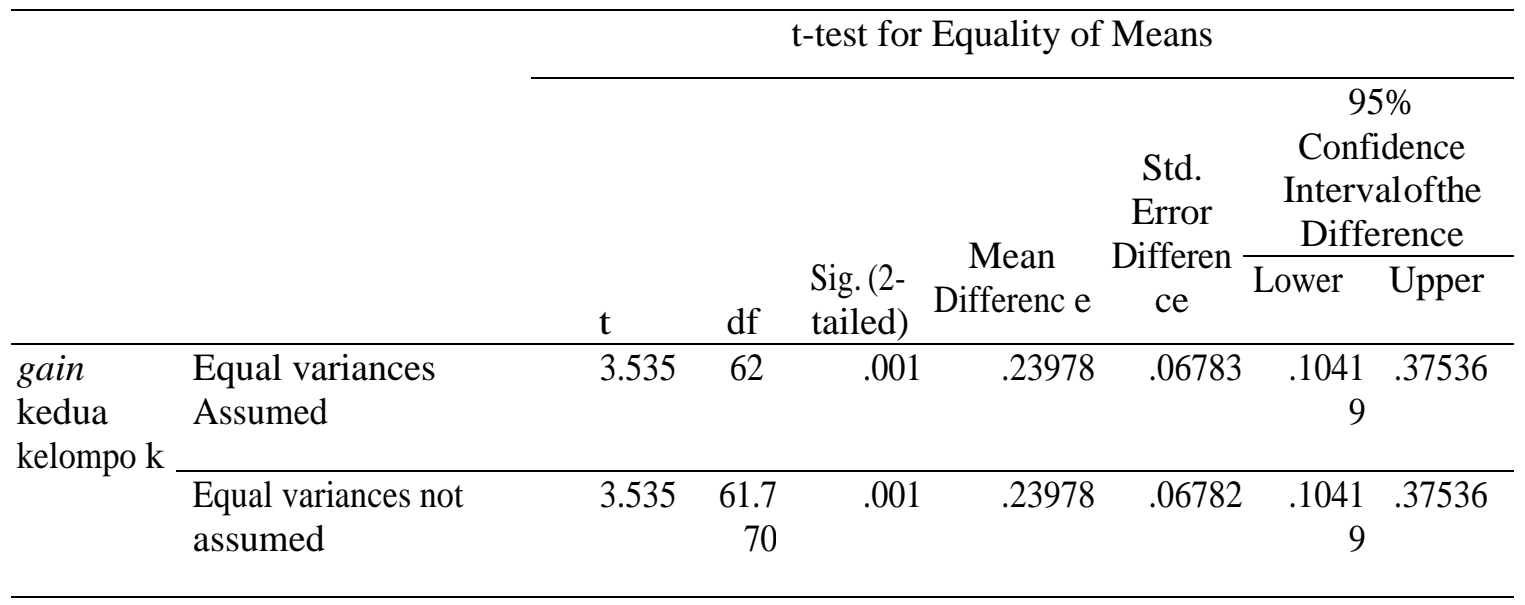

Berdasarkan hasil uji kuantitatif di atas didapatkan $P$-value (Sig. 2-tailed) sebesar 0,001 dengantaraf signifikansi $\alpha=0,05$. Hal ini menunjukkan nilai signifikansi lebih kecil dari 0,05 sehingga $H_{0}$ ditolak. Dengan demikian $H_{1}$ diterima yang artinyaterdapat perbedaan peningkatan keterampilan berpikir kreatif antara siswa yang menggunakan model pembelajaran project based learning dengan konvensional. Dapat diambil 
kesimpulan, bahwa dengan menggunakan model project based learning lebih mampu meningkatkan keterampilan berpikir kreatif daripada menggunakanmodel pembelajaran konvensional.

Kreativitas mahasiswa pendidikan kimia, dilihat dari beberapa indikator kreativitas yaitu fluency of thinking, flexibility, elaboration dan originality dapat dilihat pada tabel 4.

Tabel 4. Hasil indikator kreativitas kelas kontrol dan eksperimen

\begin{tabular}{ccc}
\hline Aspek Kreativitas & Kelas Kontrol & Kelas Eksperimen \\
\hline Fluency of thinking & 55 & 80 \\
\hline Flexibility & 60 & 72 \\
\hline Elaboration & 52 & 78 \\
\hline Originality & 65 & 85 \\
\hline
\end{tabular}

Sehingga pada kelas kontrol pada aspek kreativitas diperoleh rata-rata 58\% dengan kategori cukup kreatif dan pada kelas eksperimen dengan rata-rata 78,75\% dengan kategori kreatif. Persentase kreativitas pada kelas kontrol sebesar 52\% dengan kategori kurang kreatif dan pada kelas eksperimen dengan persentase $73 \%$ dengan kategori kreatif. Berikut gambar 1. grafik indikator kreativitas

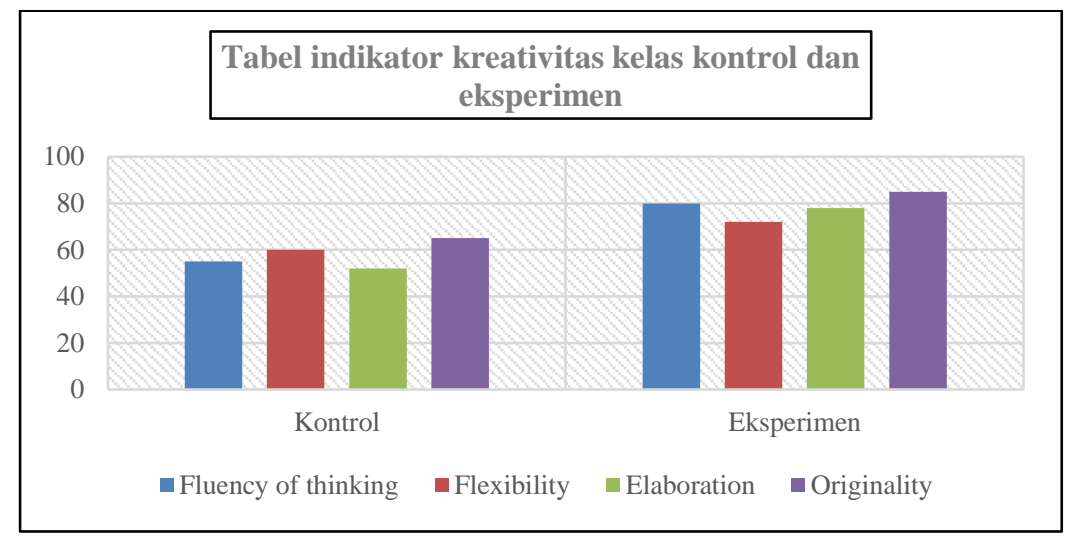

Gambar 1. Grafik indikator kreativitas kelas eksperimen dan kontrol

\section{KESIMPULAN}

Berdasarkan hasil uji kuantitatif di atas didapatkan P-value (Sig. 2-tailed)sebesar 0,001 dengantaraf signifikansi $\alpha=0,05$. Hal ini menunjukkan nilai signifikansi lebih kecil dari 0,05 sehingga $H_{0}$ ditolak. Dengan demikian $H_{1}$ diterima yang artinyaterdapat peningkatan keterampilan berpikir kreatif antara mahasiswa yang menggunakan model pembelajaran project based learning dengankonvensional.Dapat diambil kesimpulan bahwa terjadi peningkatan kreativitas mahasiswa dengan menggunakan model project based learning dalam mengidentifikasi kadar merkuri pada krim pemutih wajah tidak terdaftar. 


\section{DAFTAR PUSTAKA}

Boty, Middya. 2018. "Hubungan Kreativitas Dengan Hasil Belajar Siswa Kelas V Mata Pelajaran Bahasa Indonesia Di Mi Ma’had Islamy Palembang”. JIP:Jurnal Ilmiah PGMI. Volume 4, Nomor 1, Juni 2018.

Febrianti, Yeyen., Djahir Yulia., Fatimah, Siti. Analisis Kemapuan Berpikir Kritis Peseta Didik Dengan Memanfaatkan Lingkungan Pada Mata Pelajaran Ekonomi Di SMA Negeri 6 Palembang. Jurnal Profit. Volume 3 Nomor 1, Mei 2016.

Project Based Learning Terintegrasi STEM untuk Meningkatkan Hasil Belajar dan Kreativitas Siswa Pada Kompetensi Dasar Teknologi Pengolahan Susu". Jurnal Penelitian Pendidikan. Vol. 35 Nomor 1 Tahun 2018.

Hamalik, Oemar. 2009. Proses Belajar Mengajar. Jakarta: Bumi Aksara.

Hartono, Puji, Deni dan Asiyah, Siti. 2018. "PjBL untuk Meningkatkan Kreativitas Mahasiswa: Sebuah Kajian Deskriptif tentang Peran Model Pembelajaran PjBL dalam Meningkatkan Kreativitas Mahasiswa." Makalah pada Seminar Nasional Program Studi Pendidikan Geografi Perguruan Tinggi PGRI Palembang.

Jatmiko, B., rahani, B. K., Munasir, S., Wicaksono, I., Erlina, N., \& Pandiangan, P. (2018). The Comparisonof OR-IPA Teaching Model And Problem Based Learning Model effectiveness to Improve Critical Thinking Skills Of Pre-Service Physics Teachers. Journal Of Baltic Science Education, 17(2), 300.

Kristanti, Dyah, Yulita, dkk. 2016. "Model Pembelajaran Berbasis Proyek (Project Based Learning) Pada Pembelajaran Fisika.” Jurnal Pembelajaran Fisika, Vol. 5 No. 2, September 2016, hal 122 - 128.

Magdalena, Ina, dkk. 2021. Analisis Validitas, Realibilitas, Tingkat Kesulitan Dan Daya Beda Butir Soal Ujian Akhir Semester Tema 7 Kelas III SDN Karet 1 Sepatan. Bintang Jurnal Pendidikan dan Sains. Vol 3 Nomor 2. 198-214.

Parekuan, dkk. 2013. Analisis Kandungan Merkuri Pada Krim Pemutih Yang Beredar di Kota Manado. PHARMACON Jurnal Ilmiah Farmasi. UNSRAT. Vol 2. No 01.

Sari, Taula, Rona dan Angreni, Siska. 2018. "Penerapan Model Pembelajaran Project Based Learning (PjBL) Upaya Peningkatan Kreativitas Mahasiswa”. Varia Pendidikan, Vol. 30, No. 1, Juli 2018 : 79-83.

Sanjaya, Wina. 2010. Strategi Pembelajaran Berorientasi Standar Proses Pendidikan. Jakarta: Kencana.

Titu, Anita, Maria. 2015. "Penerapan Model Pembelajaran Project Based Learning (PjBL) untuk Meningkatkan Kreativitas Siswa pada Materi Konsep Masalah Ekonomi.” Prosiding Seminar Nasional 9 Mei 2015. Universitas Negeri Surabaya. 